\title{
Mengembangkan Potensi Kecerdasan Spiritual Anak Usia Dini Implikasi Bimbingannya
}

\author{
Rifda El Fiah
}

\author{
Dosen Fakultas Tarbiyah dan Keguruan, IAIN Raden Intan Lampung
}

Diterima: Oktober 2014. Disetujui: November 2014. Dipublikasikan: Desember 2014

\begin{abstract}
Abstrak: Mengingat begitu pentingnya kecerdasan spiritual bagi individu untuk menemukan kebahagiaan dan kebermaknaaan hidupnya yang sebenarnya maka para pendidik seharusnya sejak dini mengenali, memahami, dan mengembangkan kecerdasan tertinggi ini. Dengan pemahaman dan pengenalan sejak awal diharapkan upaya pembangunan karakter (character building) menghasilkan bangunan pribadi yang kokoh sebagai pijakan untuk membangun sumber daya manusia indonesia yang lebih berkualitas.
\end{abstract}

Kata Kunci: Potensi, Kecerdasan spiritual, Kebermaknaan dan Kebahagiaan hakiki, SDM berkualitas, Bimbingan, Anak usia dini.

\section{Pendahuluan}

Kecerdasan intelektual (IQ) yang selama ini dibangga-banggakan, akhirnya runtuh dengan temuan tentang kecerdasaran emosional (EQ). Kecerdasan intelektual hanya menyumbang tidak lebih dari $20 \%$ terhadap keberhasilan seseorang sisanya yakni $80 \%$ justru ditentukan oleh faktor lain termasuk kecerdasan emosional (Sukidi, 2000). Temuan Howard Gardner tentang multiple intelegensi yang meyakini bahwa individu memiliki banyak kecerdasan bukan hanya intelektual telah membuka cakrawala baru tentang potensi manusia yang belum dieksplorasi manusia yang belum dieksplorasi untuk mendorong keberhasilan hidup. Riset di bidang psikologi terus berkembang sampai akhirnya Solovey dan Mayer (1996) menemukan kecerdasan emosional sebagai salah satu faktor penting bagi kesuksesan hidup manusia. Temuan Solovey dan Mayer (1996) tersebut disempurnakan oleh Patton (1997) dan Goleman (1999) (Nugroho 2003).

Berdasarkan sejumlah riset dapat diketahui keunggulan kecerdasan emosi yang ternyata bisa demikian jauh mendahului kecerdasan otak (IQ) dalam berkompetensi. Antara teori IQ dan EQ tersebut hanya menekankan atau berorientasi pada kebendaan dan hubungan manusia semata yang bersifat sementara. Oleh sebab itu orang mengakui adanya Tuhan atau kekuatan yang luar biasa selain manusia akan mencari tujuan yang abadi, jangka panjang, dan mutlak. Teori yang mencapai kesemuanya itu adalah kecerdasan spiritual (SI/SQ). Individu yang cerdas secara spiritual bukan hanya mampu memecahkan persoalan hidup secara rasional atau emosi saja, Namun ia menghubungkan dengan makna kehidupan secara spiritual.

Beberapa alasan yang memperkuat alasan pemikiran pentingnya pendidikan anak sejak dini menurut Muslihuddin dan Agustin (2008: 2) adalah sebagai berikut.

1. Laporan hasil analisis Tim Education for All (pendidikan untuk semua) Indonesia tahun 2000 yang menyatakan bahwa pada tahun 2000 dari 26 juta anak Indonesia usia 0-6 tahun, lebih $80 \%$ belum mendapatkan layanan pendidikan anak usia dini. Khususnya anak usia 46 tahun yang berjumlah 12 juta baru sekitar 2 juta yang terlayani di Taman Kanak-kanak dan Raudatul Athfal (TK/RA).

2. Hasil penelitian yang menyebutkan bahwa masa usia dini adalah periode kritis dalam perkembangan anak, karena hasil kajian neurologi menunjukkan bahwa saat lahir otak bayi membawa potensi sekitar 100 milyar sel-sel syaraf yang pada proses berikutnya berkembang dengan pesat dengan menghasilkan bertriliyun-triliyun sambungan antar 
neuron. Agar tercapai perkembangan sambungan yang optimal dan berpengaruh terhadap kecerdasan anak maka harus diperkuat dengan stimulus psikososial, karena tanpa stimulus sambungan tersebut dapat melemah (atropi) bahkan musnah.

3. Fase ini disebut usia emas (golden age), dari aspek pendidikan dan pembimbingan stimulasi dini sangat diperlukan, karena setelah perkembangan ini lewat maka beberapa pun kapabilitas kecerdasan yang dicapai individu, tidak akan mengalami peningkatan lagi atau dengan kata lain tidak memiliki kebermaknaan.

4. Di sisi lain periode ini disebut juga dengan masa yang paling penting dalam rentang kehidupan individu karena merupakan waktu bagi anak untuk mulai mengenal sekolah, usia awal berkelompok, usia menjelajah, usia bertanya, usia meniru, usia kreatif, dan usia bermain (Surya, 2001: 51).

Anak usia dini merupakan fase perkembangan individu 0-6 tahun namun untuk kepentingan tulisan ini yang dimaksud dengan usia dini anak anak 4-6 tahun yaitu anak usia taman kanak-kanak/raudatul athfal (TK/RA), saat anak mulai memiliki kesadaran tentang dirinya sebagai pria dan wanita, mulai mampu mengatur diri dalam toilet training, dan mulai mengenai sejumlah hal yang dianggap bisa membuat dirinya celaka. Pada fase ini anak memiliki karakteristik perkembangan sebagai berikut.

1. Perkembangan Fisik-Motorik Hurlock

(1990:90), mengemukakan perkembangan fisik dan motorik anak usia TK adalah mencakup hal-hal sebagai berikut. a) Sistem syaraf, berkaitan erat dengan perkembangan kecerdasan dan emosi; b) Otot-otot yang bepengaruh terhadap kekuatan dan kemampuan motorik; c) Kelenjar endokrin, menjadi penyebab timbulnya sejumlah pola perilaku baru; d) Struktur fisik/tubuh yang meliputi tinggi, berat, dan proporsi tubuh; e) Pertumbuhan fisik setiap anak adalah unik (tidak selalu sama) f) Berkenaan dengan perkembangan fisik ini, Curtis (Yusuf, 2000: 164) menganjurkan agar anak diberikan kesadaran akan kemampuan sensorisnya dan konsep diri yang positif dengan pengenalan terhadap nama dan bagian tubuhnya, fungsi tubuhnya, keunikan setiap individu, keterbatasan individu, perubahan fisik yang konstan, pentingnya tidur, kesadaran sensori (panca indera), keterbatasan fisik (sakit, lelah).

2. Perkembangan Intelektual Pada fase ini menurut Piaget anak berada pada periode preoperasional, yaitu tahapan dimana anak belum mampu menguasai operasi mental secara logis. Dalam hal ini, yang dimaksud dengan operasi adalah kegiatan-kegiatan yang diselesaikan secara mental, dan bukan fisik. Periode ini ditandai dengan berkembangannya representasional atau "simbolic funtion", yaitu kemampuan menggunakan sesuatu untuk merepresentasikan sesuatu yang lain dengan menggunakan simbol berupa kata-kata, gesture, dan benda (Yusuf, 2000: 165).

3. Perkembangan Emosional Pada usia empat tahun anak sudah mulai menyadari akunya, bahwa akunya berbeda dengan akunya orang lain. Ia memahami bahwa keinginannya berhadapan dengan keinginan orang lain, sehingga tidak selamanya orang lain mampu memenuhi keinginannya. Beberapa jenis emosi yang berkembang pada masa anak adalah, takut, cemas, marah, cemburu, gembira, senang, kasih sayang, dan ingin tahu.

4. Perkembangan Sosial Pada fase ini perkembangan perilaku sosial antara lain tercermin dari perilaku anak sesuai dengan harapan lingkungan dan belajar memainkan peran sosial saat bermain dengan teman sebayanya. Menurut Hurlock (1990) perkembangan social merupakan perolehan kemampuan bersikap yang sesuai dengan tuntutan sosial.

5. Perkembangan Bahasa Kemampuan berbahasa yang khas dari usia ini antara lain: a) Anak sering mengajukan sejumlah pertanyaan (mengapa begini mengapa begitu, ini apa itu apa, dan lain-lain) b) Curiositinya sangat mendukung (sejalan dengan) kemampuan berbahasanya, "kenapa nggak boleh", "gimana bikinnya Bu", dan pertanyaan lainnya yang 
menjadi modal penting dalam perkembangan bahasanya. c) Anak usia 4-5 tahun kalimat anak sudah terdiri dari empat sampai lima kata dan usia 5-6 tahun terdiri enam sampai delapan kata. Anak juga mulai dapat menjelaskanmakna kata yang sederhana, dan mengetahui lawan kata. Diakhir usia prasekolah anak sudah mampu berkata-kata dan berbahasa sederhana secara lancar walaupun masih salah dalam berbahasa. Menurut Marat (Muslihuddin dan Agustin, 2008: 15) kemampuan berbahasa anak beririsan dengan kemampuan intelektual.

6. Perkembangan Bermain Bermain mengandung nilai-nilai psikologis dan pedagogis yang sangat berharga bagi anak, antara lain (a) memperoleh perasaan senang, puas, bangga, atau berkatarsis, (b)mengembangkan self-confidence, kooperatif, tanggung jawab mengembangkan daya fantasi dan kreativitas, (d) Memahami adanya kekurangan yang terdapat pada dirinya dan orang lain, (e) mulai mengenal aturan dan berupaya menaatinya, (f) sportif dan toleran. Menurut Ahmadi (Yusuf, 2000: 172) terdapat sejumlah bentuk permainan anak usia dini dimana kegiatan ini dilakukan dengan kebebasan batin untuk memperoleh kesenangan, yaitu (a) permainan fungsi, (b) permainan fiksi, (c) permainan reseptif dan apresiatif, (d) permainan konstruksi, dan (e) permainan prestasi.

7. Perkembangan Kepribadian Fase ini sebut masa trotzalter (krisis/menantang) pertama karena perkembangan kepribadian anak sedang bergerak dari sikap dependen ke independen dan bersikap egosentris (Hurlock, 1999). Saat ini anak mulai menyadari bahwa keinginannya tidak selalu dipenuhi orang lain, karena itu mereka meresponnya dengan sikap membandel (keras kepala). Namun pada usia ini juga mulai berkembang kesadaran dan kemampuan untuk memenuhi tuntutan dan tanggung jawab, untuk itulah pembimbing seyogyanya menyikapi dengan lembut, bijaksana, dan penuh kasih sayang. Karena meskipun mereka ingin independen tetapi pada hakikatnya mereka sangat mengharapkan perhatian, cinta dan kasih sayang dari orang tua.

8. Perkembangan Moral dan Kesadaran Religius Anak mulai mengenal konsep baik buruk, benar salah, kedisiplinan, dan memiliki sikap dasar moralitas terhadap kelompok sosialnya, apa yang boleh dan tidak boleh dilakukan. Pemahaman ini diperoleh melalui interaksi, latihan, dan pembiasaan dalam kelompok sosialnya tersebut. Adapun karakteristik kesadaran beragama anak usia dini menurut Makmun (Yusuf, 2000: 176), antara lain (a) sikap keagamaannya reseptif walau banyak bertanya, (b) pandangan ketuhanannybersifat anthromorph, (c) penghayatan ruhaniahnya superficial, dan (d) hak ketuhanan dipahamkan secara ideosyncritic.

\section{Pentingnya Mengembangkan Potensi Kecerdasan Spiritual Anak Sejak Dini "Setiap} Anak dilahirkan dalam keadaan fithrah, Orang tuanyalah yang meyahudikannya, menasranikannya, atau memajusikannya" (Al Hadits). Dalam Islam dipercayai bahwa setiap individu yang dilahirkan membawa fithrah. Anak dilahirkan dengan kecerdasan spiritual yang tinggi, tetapi perlakuan orangtua dan lingkungan yang menyebabkan mereka kehilangan potensi spiritual tersebut. Betapa jelas bunyi hadits di atas, bahwa karena tangan orang tuanyalah anak dapat berubah arah, yang tadinya fithrah malah menyimpang. Padahal pengembangan kecerdasan spiritual sejak dini akan memberi dasar bagi terbentuknya kecerdasan intelektual dan emosional pada usia selanjutnya. Di sinilah pentingnya pembimbingan dari orang tua, guru, dan pendidik lainnya agar mereka menyadari dan menjadikan pendidikan dan pembimbingan pada fase ini jangan sampai terabaikan, khususnya dalam upaya pengembangan kecerdasan spiritual. Munculnya krisis akhlak yang menimpa Indonesia saat ini berawal dari lemahnya penanaman nilai spiritualitas terhadap anak sejak dini. Pembentukan akhlak terkait erat dengan kecerdasan emosi, sementara itu kecerdasan itu tidak akan berarti tanpa ditopang oleh kecerdasan spiritual. Prasekolah atau usia balita adalah awal yang paling tepat untuk menanamkan nilai-nilai spiritual kepada anak. 
Tetapi apa yang terjadi sebenarnya? Anak lebih banyak dipaksa untuk mengeksplorasi bentuk kecerdasan yang lain, khususnya kecerdasan intelektual, sehingga anak sejak awal sudah ditekankan untuk selalu bersaing untuk menjadi yang terbaik, sehingga menyebakan tercerabutnya kepekaan anak. Sementara itu lingkungan keluarga maupun lingkungan masyarakat kurang memberikan dukungan terhadap penumbuhan dan pengembangan kecerdasan spiritual pada anak. Di lingkungan keluarga anak lebih banyak berinteraksi dengan sesuatu yang justru menyebabkan semakin jauhnya kepekaan anak, bahkan yang lebih parah lagi apabila proses dehumanisasi itu terjadi justru di tengah lingkungan keluarga. Keluarga sebagai tempat pendidikan yang utama dan pertama malahan kering dari aspek pedagogis.

Gaung kecerdasan spiritual diteriakkan oleh Donah Zohar dan Ian Marshal pada awal tahun 2000. Dikatakan oleh Zohar dan Marshal (2001: 3) Kecerdasan spiritual dapat menjadi sumber motivasi yang memiliki kekuatan maha dahsyat, dan merupakan landasan yang diperlukan untuk memfungsikan intelligence quotient (IQ) dan emosional intelligence (EI) secara efektif bahkan merupakan kecerdasan tertinggi manusia.

Sebenarnya kecerdasan spiritual sudah dikenal sejak peradaban Islam ada di muka bumi ini. Menurut Seto Mulyadi, kecerdasan spiritual adalah bagaimana manusia dapat berhubungan dengan Sang Pencipta (Ummi, edisi 4, 2002). Dengan kata lain kecerdasan spiritual adalah kemampuan manusia untuk mengenali potensi fitrah dalam dirinya serta kemampuan seseorang mengenali Tuhannya yang telah menciptakannya, sehingga di manapun berada merasa dalam pengawasan Tuhannya. Gutama (2002: 33) mengatakan bahwa kecerdsan spiritual tidak hanya terkait dengan akal, tetapi dengan hati dan jiwa atau roh. Roh (ruh) adalah prinsip yang menghidupkan (vital) atau sesuatu yang menghidupkan bahkan nafas kehidupan itu sendiri.

Arief Rachman (2006) melukiskan bahwa kecerdasan spiritual adalah (a) kecerdasan yang meyakini Tuhan sebagai Penguasa, Penentu, Pelindung, Pemaaf dan kita percaya atas Kehadiran-Nya, (b) kemampuan untuk bekerja keras, kemampuan untuk mencari ridho Allah, kemampuan untuk melakukan ibadah secara disiplin, kesabaran, tahan dengan ujian dan kemampuan untuk menerima segala keputusan yang telah ditetapkan Allah.

Secara ilmiah potensi dan bakat keceradasan spiritual anak telah dibawa sejak lahir telah dibuktikan oleh beberapa kajian (Sinetar, 2002), yang mengatakan bahwa potensi-potensi pembawaan spiritual (spiritual trait) pada anak antara lain adalah sifat keberanian, optimisme, keimanan, perilaku konstruktif, empati, sikap memaafkan, dan bahkan ketangkasan dalam menghadapi amarah dan bahaya. Semua itu menjadi sifat-sifat spiritual anak-anak sejak usia dindmigen 1. Kesadaran diri yang mendalam, intuisi, dan kekuatan "keakuan" atau otoritas bawaan.

2. Pandangan luas terhadap dunia: melihat diri sendiri dan orang-orang lain saling terkait; menyadari tanpa diajari bahwa bagaimanapun kosmos ini hidup dan bersinar; memiliki sesuatu yang disebut "cahaya subyektif"

3. Moral tinggi, pendapat yang kokoh, kecenderungan untuk merasa gembira, "pengalaman puncak" (peak experience) dan atau bakat-bakat estetis.

4. Pemahaman tentang tujuan hidupnya; dapat merasakan arah nasibnya; melihat berbagai kemungkinan, seperti cita-cita suci atau sempurna, dari hal-hal yang biasa.

5. "Kelaparan yang tidak dapat dipuaskan" akan hal-hal tertentu yang diminati, acapkali membuat mereka menyendiri atau memburu tujun tanpa berpikir lain; pada umumnya mementingkan kepentingan orang lain (altruistis) atau keinginan berkontribusi kepada orang lain.

6. Gagasan-gagasan yang segar dan "aneh", dan rasa humor yang dewasa. 
7. Pandangan pragmatis dan efisien tentang realitas, yang sering (tetapi tidak selalu) menghasilkan pilihan-pilhan sehat dan hasil-hasil praktis.

\section{Metode Penelitian}

Mempertimbangkan kelangkaan penelitian tentang pengembangan potensi kecerdasan spiritual anak usia dini, maka penelitian ini berusaha menjelaskan tentang apa dan bagaimana perlakuan, beserta pentingnya pendidikan anak sejak dini. Tujuannya yaitu memberikan suatu wacana tambahan tentang tentang pengembangan potensi kecerdasan spiritual anak usia dini. Penelitian ini menggunakan pendekatan kualitatif dengan menerapkan metode penelitian kepustakaan (library research). Penelitian berbasis literatur merupakan bentuk penelitian yang menggunakan literatur sebagai obyek kajian. Pendekatan ini sangat sesuai untuk kondisi Indonesia karena masih terbatasnya pemahaman tentang pengembangan potensi kecerdasan spiritual anak usia dini. Data yang digunakan dalam penelitian ini berupa data sekunder, yaitu buku-buku, majalah-majalah dan dokumen-dokumen tertulis. Selain itu digunakan juga artikelartikel yang diambil dari jurnal. Sedangkan untuk menjawab permasalahan, teknik analisis yang digunakan adalah teknik content analysis. Dalam teknik ini diperlukan data untuk menjawab setiap tahap penelitian, kemudian dilakukan content analysis terhadap data tersebut untuk menjawab atau mendeskripsikan pertanyaan penelitian pada tahap tersebut. Hasil content analysis ini kemudian digunakan sebagai bahan untuk menjawab pertanyaan penelitian pada tahap selanjutnya bersama dengan data lain yang diperoleh.

\section{Hasil dan Pembahasan}

Menurut Jalaluddin Rahkmat (2007: 18) berdasarkan penelitian, anak yang memiliki kecerdasan spiritual tinggi rasa ingin tahunya semakin besar, sehingga memiliki dorongan untuk selalu belajar serta memiliki kreativitas yang tinggi pula. Kecerdasan spiritual dapat ditumbuhkan pada anak dengan cara membersihkan hatinya lebih dahulu. Dengan hati yang bersih maka aktivitas yang lainnya akan menjadi lebih mudah. Menurutnya untuk mengotimalkan kecerdasan spiritual pada anak dapat dilakukan dengan cara: Pertama, membantu anak untuk merumuskan tujuan hidupnya, baik tujuan hidup jangka pendek maupun tujuan hidup jangka panjang. Kedua, sesering mungkin orangtua menceritakan kisah-kisah yang agung, kisah yang menarik dan mengesankan, seperti kisah para Rasul, atau pahlawan lainnya. Ketiga, mendiskusikan segala persoalan dengan perspektif ruhaniyah. Keempat, sering melibatkan anak dalam ritual kegaamaan, seperti dilatih sejak kecil untuk sholat berjamaah bagi anak laki- laki, selalu membaca doa, dan yang terpenting adalah pemaknaan dari kegiatan tersebut. Kelima, membawa anak kepada orang yang menderita dan kematian. Mengunjungi orang yang menderita akan membuat anak peka terhadap sesama sehingga mendorong anak untuk berbuat baik terhadap orang lain. Keenam, bacakan puisi atau lagu-lagu yang spiritual dan inspirasional. Ini yang disebut spiritual intelligence (SI)). SI harus dilatih, dan salah satu caranya ialah menyanyikan lagu-lagu keagamaan (nasyid) atau membacakan puisi-puisi.

Ketujuh, bawa anak untuk menikmati keindahan alam. Bawalah anak-anak pada alam yang relatif belum banyak tercemari. Ajak mereka menjelajahi puncak gunung, rasakan udara yang segar dan sejuk, dengarkan burung-burung yang berkicau, nikmati deburan ombak di pantai dan seterusnya. Sediakan waktu khusus bersama mereka untuk menikmati ciptaan Tuhan.

Terkait dengan prinsip bimbingan dan konseling untuk anak usia dini Syaodih, E dan Agustin, M (2008: 1.8 - 1.11) menjelaskan bahwa pelaksanaan layanan bimbingan untuk anak usia dini perlu memperhatikan prinsip-prinsip sebagai berikut.

1. Bimbingan bagian penting dari proses pendidikan.

2. Bimbingan diberikan kepada semua anak dan bukan hanya untuk anak yang mengahadapi masalah. 
3. Bimbingan merupakan proses yang menyatu dalam semua kegiatan pendidikan.

4. Bimbingan harus berpusat pada anak yang dibimbing.

5. Kegiatan bimbingan mencakup seluruh kemampuan perkembangan anak yang meliputi kemampuan fisik- motorik, kecerdasan, sosial, emosional, dan spiritual.

6. Bimbingan harus dimulai denganmengenal (mengidentifikasi) kebutuhan-kebutuhan yang dirasakan anak.

7. Bimbingan harus fleksibel dan sesuai dengan kebutuhan serta perkembangan anak.

8. Dalam menyampaikan permasalahan anak kepada orang tua hendaknya menciptakan situasi aman dan menyenangkan sehingga memungkinkan terjadinya komunikasi yang wajar dan terhindar dari kesalahpahaman.

9. Dalam melaksanakan kegiatan bimbingan hendaknya orang tua diikutsertakan agar mereka dapan mengikuti perkembangan dan memberikan bantuan kepada anaknya di rumah.

10. Bimbingan dilakukan seoptimal mungkin sesuai dengan kemampuan sebagai pelaksana bimbingan, jika masalah yang terjadi perlu ditindak lanjuti maka guru pembimbing harus mengkonsultasikan kepada kepala sekolah dan tenaga ahli.

11. Bimbingan harus diberikan secara berkelanjutan.

Pelaksanaan bimbingan dan konseling bagi anak usia dini menggunakan pendekatan perkembangan, yaitu visi bimbingan yang bersifatedukatif, pengembangan, dan outreach (Kartadinata, S. 2000), dan memiliki ciri-ciri sebagai berikut.

1. Proses bimbingan dan konseling harus disesuaikan dengan pola pikir dan pemahaman anak.

2. Pelaksanaan bimbingan terintegrasi dengan pembelajaran.

3. Waktu pelaksanaan bimbingan sangat terbatas.

4. Pelaksanaan bimbingan dilaksanakan dalam nuansa bermain.

5. Adanya keterlibatan teman sebaya.

6. Ada keterlibatan orang tua (Syaodih, E, 2004).

Oleh karena kecerdasan spiritual ternyata sudah built-in dalam diri anak-anak, maka tak berlebihan sekiranya puluhan tahun lalu ahli psikiatri RD Laing yang agak keduniawian mengakui bahwa masing-masing anak adalah makhluk baru, seorang calon nabi, seorang pangeran (atau putri) spiritual yang baru, percikan cahaya baru yang menembus kegelapan luar.

Khalil A Khafari (Sukidi, 2002) dalam bukunya "Spiritual Intelligence, A Practical Guide to Personal Happiness" mengungkapkan, perspektif kecerdasan spiritual sebagai pembimbing untuk meraih kebahagiaan spiritual. Sebagai makhluk spiritual, kebahagiaan manusia tidak bisa lagi diukur dengan uang, kesuksesan, kepuasan kerja, kehidupan seks, dan lain-lain, tetapi kebahagiaan yang diletakkan dalam wilayah spiritual. Individu yang mempunyai kecerdasan spiritual tinggi akan meninggalkan bekas di hati orang lain, sebab orang yang memiliki kecerdasan spiritual yang tinggi akan menjaga amanah yang diberikan kepadanya. Dia tidak akan melakukan korupsi, penggelapan uang rakyat dan sebagainya, sebab dimanapun dia berada, orang yang cerdas secara spiritual akan merasa selalu diawasi sang pencipta, Allah SWT.

\section{Simpulan dan Saran}

Berdasarkan deskripsi dan uraian di atas dapatlah disimpulkan bahwa pengenalan dan pemahaman kecerdasan spiritual anak sejak dini bagi para pendidik sangatlah penting. Mengingat merekalah peletak pondasi pertama pada pemahaman dan penerapan sikap religi pada anak didiknya guna meningkatkan kecerdasan spiritual mereka. Dengan mengenali dan memahami serta meningkatkan kecerdasan spiritual anak sejak dini diharapkan para pendidik 
dan pembimbing dapat memberikan bantuan dan perlakuan yang dapat menstimulasi potensi kecerdasan spiritual anak yang memang sudah melekat dalam dirinya sejak ia berada di dunia ini.

Adanya perlakuan yang optimal diharapkan anak sebagai generasi penerus bangsa ini akan memiliki karakter dan kepribadian yang memang sangat diharapkan yakni menjadi tulang punggung pembangunan bangsa ini. Diharapkan kelak anak bukan hanya memiliki kemampuan intelektual dan emosional yang tinggi namun berkepribadian lebih berkualitas dengan nilai-nilai spiritualitas-religiusitas serta mampu memaknai setiap perilaku dan perbuatannya; dan perkembangan anak dini bangsa ini dapat menjadi generasi yang mampu membawa bangsa ini menjadi adil dan makmur.

\section{Daftar Pustaka}

Abdullah, Abdurahman, (2002) Aktualisasi Konsep Dasar Pendidikan Islam. Yogyakarta: UUI Presss.

Ahman, (1998) Model Bimbingan dan Konseling Perkembangan di SD. Tesis, PPS IKIP Bandung, tidak diterbitkan.

An-Nahlawi, A., (1996) Pendidikan Islam Di Rumah, Sekolah, dan Masyarakat, (terj. Sihabuddin) Jakarta: Gema Insani Press.

Agustin, M. (2006) Program Bimbingan untuk Mengembangkan Kecerdasan Jamak (Multiple Intellegences Anak Usia Taman Kanak-kanak. Bandung: Universitas Pendidikan Indonesia. Tesis tidak diterbitkan.

Dedi Supriadi, Antara Taman Kanak-kanak dan Sekolah Dasar: Dibalik Kebijakan Ada Konstruk Berfikir, makalah pada Direktorat Pendidikan Dasar, Jakarta: Depdiknas.

Depdiknas, (2002) Kompetensi Dasar Pendidikan Anak Usia Dini 4-6 Tahun. Jakarta: Puskur Depdiknas, (2002) Buletin Padu (Edisi 02). Jakarta:

Proyek Paud Dirjen PLSP, (2003) Early Childhood Care and Educational in Indonesia. Jakarta: Dirjen PLSP Direktorat Padu.

Fasli Jalal, (2002) Pentingnya Pendidikan Anak Usia Dini dalam Membangun Masa Depan Bangsa yang Berkualitas, makalah pada Seminar dan Diskusi Panel Membangun Masa Depan Jawa Barat Melalui Peningkatan Layanan PAUD, UPI Bandung.

Gutama, (2002) Kecerdasan Spiritual Dalam Membentuk Perilaku Anak, buletin Padu, Jurnal Ilmiah Anak Dini Usia, Edisi 02 Okt. 2002.

Hurlock, Elizabeth, B. (1999) Psikologi Perkembangan (terj. Istiwidayanti) Jakarta: Erlangga. Jalaluddin Rahmat, (2007) SQ for Kids : Mengembangkan Kecerdasan Spiritual Anak Sejak Dini. Bandung: Mizan.

Mamat Supriatna dan A.J. Nurihsan (ed), (2005) Pendidikan dan Konseling di Era Global dalam Perspektif Prof. Dr. M. Djawad Dahlan. Bandung: Rizqi Press .

M. Surya (2002) Dasar-dasar Bimbingan dan Konseling. Bandung: Jurusan PPB FIP UPI Bandung.

Patmonodewo, S. (2000) Pendidikan Anak Prasekolah. Jakarta: Depdiknas \& Rineka Cipta. Rahmat, J. (2007) SQ for Kids: Mengembangkan Kecerdasan Spiritual Anak Sejak Dini. Bandung: Mizan

Syaodih, E. (2007) Model Bimbingan Perkembangan di Taman Kanak-kanak. Disertasi SPs UPI Bandung, tidak diterbitkan.

Syaodih, E. \& Agustin, M. (2008) Bimbingan dan Konseling untuk Anak Usia Dini. Jakarta: Universitas Terbuka. 
Solehuddin dan Mubiar Agustin, (2008) Mengenali dan Mengembangkan Potensi Kecerdasan Jamak Anak Usia Taman Kanak-kanak/Raudhatul Athfal (Kajian Teoritis dan Praktis untuk Guru, dan Pendamping Anak Usia Dini). Bandung: Rizqi Press.

Seto Mulyadi, (2002) Meumbuhkan S I Anak Sejak Dini. Majalah Ummi, edisi 4, 2002

Sinetar, Marsha (2000) Spiritual Intelligence: What We Can Learn from the Early Awakening Child (pentj) Soesanto Boedidarmo (2001) Kecerdasan Spiritual: Belajar dari Anak yang Mempunyai Kesadaran Dini, Jakarta: Elex Media Komputindo.

Sukidi, (2002) Rahasia Sukses Hidup Bahagia "Kecerdasan Spiritual” Mengapa SQ lebih penting daripada IQ dan EQ, Jakarta: PT Gramedia Pustaka Utama

Syamsu Yusuf, (2002) Psikologi Perkembangan Anak dan Remaja, Bandung: Remaja Rosda Karya.

Zohar, Danah dan Marshall, Ian (2001) Memanfaatkan Kecerdasan Spiritual dalam Berfikir Integralistik dan Holistik untuk Memaknai Kehidupan (SQ: Spiritual Intelligence - The Ultimate Intelligence) (terj. Rahmani Astuti dkk. Bandung: Mizan Media Utama. 